\title{
URBAN VEGETATION AND MORPHOLOGY PARAMETERS AFFECTING MICROCLIMATE AND OUTDOOR THERMAL COMFORT IN WARM HUMID CITIES - A REVIEW OF RESEARCH IN THE PAST DECADE
}

\author{
Dissanayake $C^{*}$, Weerasinghe UGD and Wijesundara KWJP \\ University of Moratuwa, Sri Lanka
}

\begin{abstract}
Urbanization provokes major modifications to the natural landscape. As the urban population reaches $60 \%$ of the world's population by 2030, this constant development, neglecting the planning and design of open spaces, negatively affects microclimate. This leads to local climate change, urban heat islands, and outdoor thermal discomfort. This paper is based on the recent studies of urban morphology and vegetation parameters affecting urban microclimate and outdoor thermal comfort in warm, humid cities in the past decade. Results revealed that three factors are of paramount importance and affect the thermal comfort level; urban space morphology, the orientation of elements and spaces, and vegetation. Therefore, Scenario developments for micrometeorological simulations should be processed considering the identified parameters of urban morphology and vegetation which are further categorized as parameters of geometry, density, configuration, and the physical properties of plants. However, the Configuration of urban vegetation that affects the thermal comfort of urban spaces has not received adequate attention in previous research yet. Thus, future research is needed considering the planting patterns, arrangement of various species, and planting orientations with prevailing wind conditions. By the end of this review, a theoretical framework is suggested as an approach to assess the impact of urban vegetation and morphology parameters on outdoor thermal comfort in warm, humid climates. The framework guides further research adopting more specific and comprehensive approaches of urban vegetation configuration with reference to specific urban morphologies to improve the local microclimate of cities, where the space for planting is critical.
\end{abstract}

Keywords: urban vegetation, urban morphology, vegetation configuration, outdoor thermal comfort, warm humid cities, Climate change

\section{Introduction}

Urbanization provokes major modifications on natural landscape (Wei, R., Song, D., Wong, N. H., \& Martin, M. 2016) which intensifies urban heating, emissions, deforestation (including urban trees), and modification of surface energy balance (D.E. Bowler et al 2010). Accordingly, global mean surface and air temperature have been projected to increase by $2.6 \mathrm{C}-4.8 \mathrm{C}$ and $2 \mathrm{C}-4 \mathrm{C}$, respectively especially in urban areas during this century (K. Brysse et al 2012). Frequent periods of extensive heat due to global warming are expected to become a serious problem (Ndetto and Matzarakis 2015). Since half of the world's population lives in the tropics (EIU, 2011), consequences of high temperature, high humidity, and high solar radiation in urban contexts within the tropics 
should be significantly considered. Consequently, Urban Heat Island (UHI) has become a global phenomenon, and cities are developed with different development attempts which increase the energy consumption of the building, alter the urban climatology, and modify the urban wind patterns and increase the concentration of air pollutants (Wong, N. H., Jusuf, S. K., \& Tan, C. L. 2011). However, the development of tropical urban environments, ignoring proper planning and design of open spaces, negatively impacts microclimate. This leads to local climate change, urban heat islands, and outdoor thermal discomfort (Salata, Golasi, de Lieto Vollaro, \& de Lieto Vollaro, 2016). Further, local climate change causes heat stress to urbanites, resulting in negative impacts on public health and productivity in most tropical countries (Yang, W., Lin, Y., \& Li, C. Q. 2018). As mentioned by Zittis, G., Hadjinicolaou, P., Fnais, M., \& Lelieveld, J. 2016, and Lhotka, O., \& Kyselý, J. 2015 heatstroke and premature deaths occur as a result of the heat stress due to prevailing temperature extremes and higher intensity in urban areas, especially in tropical countries. Moreover, Increasing urban densities and ever-increasing urbanization trends have led to the need for appropriate strategies to improve thermal comfort and put in place proper resistance against the heating island (Zhao \& Fong, 2017).

This calls for the creation and maintenance of more thermally comfortable indoor and outdoor urban environments. Therefore, the impact on outdoor thermal comfort and microclimate due to adverse effects of urbanization have been increasingly investigated (Jamei et al., 2016; Roshan et al., 2020). Moreover, the climatic quality of outdoor spaces has attracted a great deal of attention among urban planners, landscape designers, and climatologists (El-Bardisy, Fahmy, \& El-Gohary, 2016). Though many researchers have proposed different mitigation measures in various scales for microclimatic improvements, the efficiency is still subject to argument. Due to changes in urban structures and densities, contemporary urban design is no longer capable of controlling microclimate and improving thermal comfort conditions, which has become a major challenge in contemporary urban design (Barakat, Ayad, \& El-Sayed, 2017). Due to climate change and the intensification of urban heat islands, urban design and planning should be undertaken with proper considerations given to these changes (Nasrollahi, Hatami, Khastar, \& Taleghani, 2017). The complexity of the built environment, urban design patterns considerably affect the microclimate and outdoor thermal comfort in a given urban morphology. The changes and the vast reduction of greenery, weather conditions within the urban canopy layer show the clearest signs of inadvertent modifications (Wei, R. et al 2016). Moreover, the reduction of green spaces and its' alternatives with impenetrable urban surfaces affect on reduction of wind flow and ventilation in the city, and it makes air dryness of the urban space (Robitu, Musy, Inard, \& Groleau, 2006).

Three factors are of dominant importance and affect the thermal comfort level, namely, urban space morphology, the orientation of elements and spaces, and vegetation in designing urban spaces (Yahia \& Johansson, 2014). As urban design has a significant impact on microclimate and outdoor thermal comfort, (Yahia, M. W., Johansson, E., Thorsson, S., Lindberg, F., \& Rasmussen, M. I. 2018) urban morphology influences urban microclimate, and vice versa. Different urban forms have been created in cities, which differently affect the microclimate of the city by changing the incoming solar radiation duration and the mean radiant temperature (Taleghani, Kleerekoper, Tenpierik, \& Van Den Dobbelsteen, 2015). Therefore, Climate responsive urban design has become an important and urgent task for cities. This calls for designing and maintaining thermally comfortable outdoor urban environments with alteration of urban morphology and inclusion of greenery (H. Akbari et al 1997, A.M. Coutts et al 2015). Further, it has been found that, on average, about $80 \%$ of the total cooling effect is contributed by tree shading (Yoshida et al. 2000; Shashua-Bar and Hoffman 2000. Further, 
vegetation is the most common method to alleviate the negative impacts of the UHI (Declet Barreto et al., 2013). Therefore, vegetation and green space management in urban public space is essential to improve the microclimatic conditions. Thus, researching the parameters of urban morphology and vegetation affecting microclimate and outdoor thermal comfort is indispensable to make urbanites feel comfortable and reduce the urban heat island effect and its' consequences.

This paper is based on the recent studies of urban morphology and vegetation parameters affecting urban microclimate and outdoor thermal comfort in warm, humid cities in the past decade (2010 to 2020). The objectives of the study are to critically examine previous efforts in urban vegetation and urban morphological assessments on outdoor comfort in tropical cities, to determine key vegetation and morphological parameters affecting urban microclimate and outdoor thermal comfort, to identify areas on which there has been inadequate research attention, and explore future research trends through comprehensive literature analysis. By the end of this review, a theoretical framework is suggested as an approach to assess the impact of urban vegetation and morphology parameters on outdoor thermal comfort in warm, humid cities

\section{Methodology}

This research was conducted through a comprehensive literature review on urban morphology and vegetation parameters affecting urban microclimate and outdoor thermal comfort in the past decade (2010 to 2020). This section explains the procedure followed to find, categorize and review the highly relevant sources for this review study. The inclusion and exclusion criteria were adapted in the procedure that applied in two stages. The first stage was a systematic bibliometric search through a digital screening to explore related articles in English language from the Scopus and Google Scholar databases for this systematic review. The desktop search resulted in 180 research outputs, including peer-reviewed journal articles and conference papers. To ensure that highly relevant sources were captured, the references of selected sources' references were also explored. In the second stage, the sources that had highly relevant content were shortlisted, and their full texts were downloaded. Noteworthy, the sources that had not considered either urban vegetation or morphology parameters using thermal comfort index were excluded. Further, the studies that involved human participants in their research design were also excluded. At the end of this stage, 37 research outputs remained for comprehensive content analysis.

This review is limited to warm humid cities without having a regional focus and it is important to have a regional focus to identify more relevant parameters and simulation methods. This is also limited to articles in English language and two research databases published from 2010 to 2020. Further reviews should explore the studies in terms of the thermal properties of urban surfaces instead of vegetation and morphology parameters.

\section{Content Analysis}

The papers reviewed in this study have been published in several journals, but the three journals mostly used are, Building and Environment, Urban Forestry and Urban Greening, Sustainable City and Society. The results of these studies are categorized in terms of their topics, in order to find gaps and areas that have received less attention. See appendix 1 for the summary of the review of the most relevant articles (37) related to the features of vegetation and urban morphology, the publishing journal, and the key parameters used. 


\section{Results}

All the identified parameters of urban vegetation are categorized as parameters of Geometry, density, configuration, and the physical properties of plants, while the parameters of urban morphology are categorized as Geometry, density, configuration parameters. Table 2 shows the categorization of key parameters of vegetation into Geometry, density, configuration, and the physical properties of plants which are recently taken into the investigation in thermal comfort assessments.

Table 1: Categorization of key parameters of urban vegetation.

\begin{tabular}{|c|c|}
\hline Category & Key vegetation parameters \\
\hline \multirow{7}{*}{ Geometry } & Plant area index (PAI) \\
\hline & Leaf area index \\
\hline & Canopy area \\
\hline & Crown height - crown diameter \\
\hline & Crown geometry \\
\hline & Trunk height \\
\hline & The aspect ratio of trees (ART) \\
\hline \multirow{5}{*}{ Configuration } & Planting patterns and arrangement, \\
\hline & Location (tree layout) \\
\hline & Individual or cluster planting \\
\hline & Tree layouts \\
\hline & Distance between trees \\
\hline \multirow{5}{*}{ Density } & Tree canopy density \\
\hline & Planting density \\
\hline & Canopy permeability \\
\hline & Leaf area density (LAD) \\
\hline & Vegetation cover \\
\hline \multirow{6}{*}{ Physical properties of plants } & Leaf type \\
\hline & Albedo \\
\hline & Vegetation types, tree type \\
\hline & Stem diameter \\
\hline & Tree height \\
\hline & Trees species \\
\hline
\end{tabular}

Table 2: shows the categorization of key parameters of urban morphology into Geometry, density and configuration which are recently taken into investigation in thermal comfort assessments.

\begin{tabular}{|l|l|}
\hline Category & Key urban morphology parameters \\
\hline \multirow{4}{*}{ Geometry } & Street ratio H/W \\
\cline { 2 - 2 } & Sky view factor (SVF) \\
\cline { 2 - 2 } & Building height \\
\cline { 2 - 2 } & Building orientations \\
\hline
\end{tabular}




\begin{tabular}{|l|l|}
\hline \multirow{4}{*}{ Configuration } & Green areas direction \\
\cline { 2 - 2 } & Spatial configuration of green areas \\
\cline { 2 - 2 } & Street axis orientation \\
\hline \multirow{4}{*}{ Density } & Building density \\
\cline { 2 - 2 } & Urban density and compactness \\
\cline { 2 - 2 } & Surfaces coverage ratio \\
\cline { 2 - 2 } & Greenery ratio \\
\cline { 2 - 2 } & Spaces between buildings \\
\hline & Green plot ratio \\
\hline
\end{tabular}

\section{The Cooling effect of urban vegetation}

Green infrastructures improve the microclimate by reducing hot air flows, evapotranspiration, and shading as the most efficient way to reduce the negative effect of warming urban environments (Bartesaghi et al. 2018). For the moderation of negative impacts of the UHI effect, vegetation is the most commonly used method (Declet Barreto et al., 2013). Green infrastructure, which consists of natural and semi-natural elements, provides many ecosystem services, including climate modification (Bartesaghi Koc, C., Osmond, P., Peters, A., 2018). Providing visual aesthetics for pedestrians and urban greenery accomplish beneficial microclimatic effects, including air temperature reduction, which cures the UHI effect, providing shading, improved air quality, and reduced noise levels (Dimoudi, A., \& Nikolopoulou, M. 2003). Comparing to turfgrass, trees are the most effective factor for reducing long-wave radiation exchange by blocking short-wave radiation penetration to the surface and generating evapotranspiration with less water consumption, While turf lawns and shrubbery provide surface shading (Shashua-Bar, L., Pearlmutter, D., \& Erell, E. (2011). Further, as mentioned by Ng, E., Chen, L., Wang, Y., \& Yuan, C. (2012) roof greening is not effective for human thermal comfort near the ground level, but trees are suggested to be more effective than grass surfaces in cooling pedestrian areas. The shadow and wind patterns in large open spaces have less impact on the outdoor thermal comfort in general, but for smaller spaces near the buildings, the two factors are quite fundamental (Zhang et al., 2017). Green areas have a pronounced cooling effect and reduce the ambient outdoor temperature with increased canopy densities and tree coverage densities in urban areas (Tukiran, J. M., Ariffin, J., \& Ghani, A. N. A. 2017). The main determinant of heat reduction efficiency is the foliage density which makes $60 \%$ of temperature regulation, even though other morphological characteristics of trees such as tree height, trunk height, and crown diameter are determinants of tree's heat reduction potential (Morakinyo et al., 2018). 

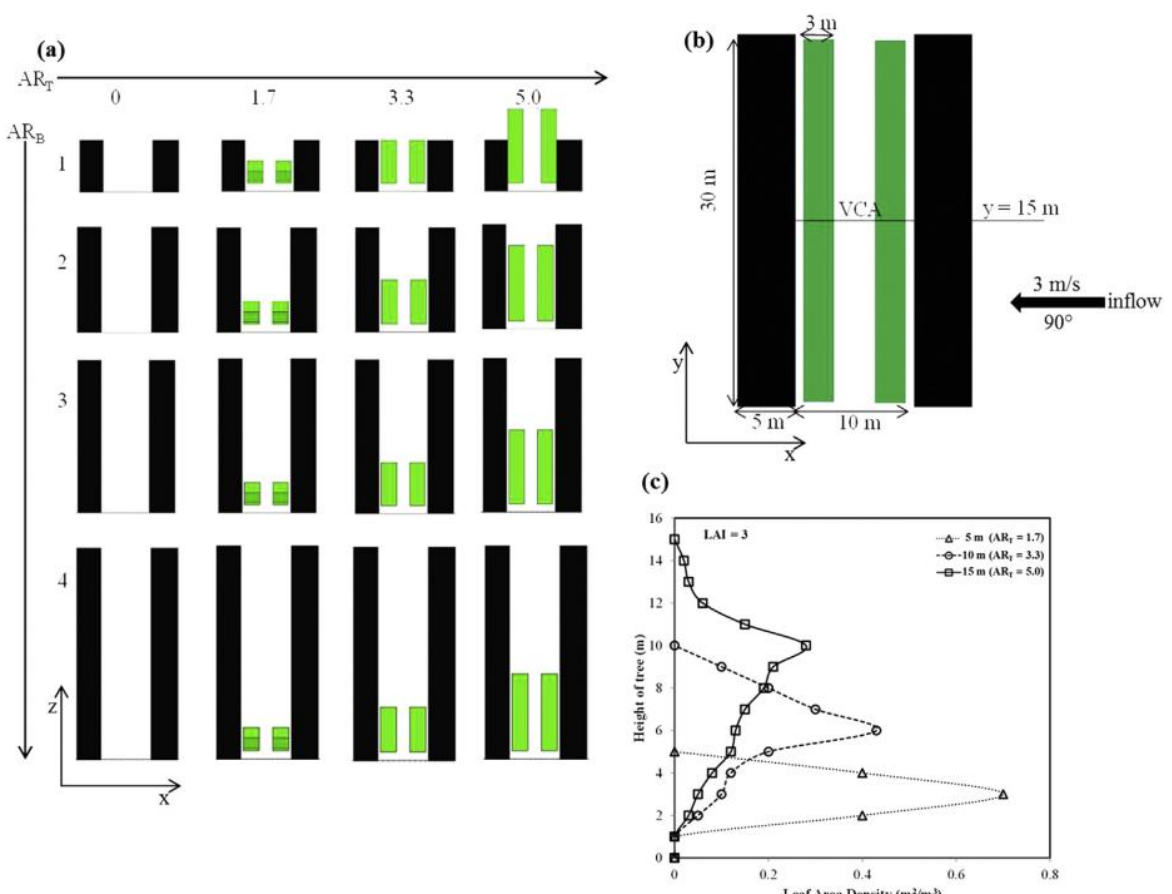

Figure 1: Schematic diagrams of different scenarios showing (a) vertical (XZ) view trees of different ART in street canyon of different ARB, (b) the XY view with the location of Vertical Cut for Analysis which was taken at the middle of the street canyon (Morakinyo et al 2016).

Thus, trees with high foliage density have high heat mitigation capacity and vice-versa for trees with low foliage density. However, heat reduction capacity can be restricted depending on the location (Morakinyo et al., 2020). According to Atwa, S., Ibrahim, M. G., \& Murata, R. (2020), the effective management of trees and higher densities affect improving thermal comfort. To maximize the average temperature cooling benefits, the tree location and arrangement should be carefully considered. Figure: 1 shows how Morakinyo et al (2016) have developed different scenarios changing the aspect ratios of trees (ART) and buildings (ARB) the embedded trees in a street canyon and further found the impact of changes in tree's aspect ratios on the PET reduction. This indicates thermal comfort benefit of trees also responsive to Leaf area density (LAD) distributing across the different height of the tree beside the LAI value while the trunk height seems to be the least important factor. Planting configurations, patterns, and physical properties of trees could be considered concerning different urban morphologies, especially in asymmetrical canyons representing real urban street canyons, for more generalized conclusions in further research. Configuration of urban vegetation that affects thermal comfort of urban spaces has not received adequate attention in previous research yet. Future studies on the effects of planting patterns, arrangement of various species, diverse tree forms and shrubs, the connection of green spaces in the landscape, planting directions with prevailing wind conditions in microclimate enhancements are needed.

\section{Impact of Urban Morphology on Microclimate}

Different urban forms in cities change the duration of direct sunlight access and the mean radiant temperature, and each of these forms has diverse effects on the microclimate of the city (Taleghani, Kleerekoper, Tenpierik, \& Van Den Dobbelsteen, 2015). Creating diverse urban forms, streets are prominent in urban landscapes. Height/width (H/W) ratio, sky view factor (SVF), and the orientation 
defined by its long axis are the determinant factors of street geometry. This directly influences the transformation of incoming solar and outgoing longwave radiation, which significantly impacts the temperature variations in the surrounding environment (Urban Heat Island) (Bourbia, F., \& Boucheriba, F. 2010). Increased (H/W) ratio gives less cooling benefits especially when it increases 1. Therefore, the proper planting arrangement at the pedestrian level is important where human activities are concentrated. (Ng, E., Chen, L., Wang, Y., \& Yuan, C. 2012 \& Morakinyo et al 2017). Further, the results of the previous studies have revealed that canyons with higher $\mathrm{H} / \mathrm{W}$ aspect ratios increase wind velocity and shading by improving thermal comfort at the pedestrian level. But the street length to building height $(\mathrm{L} / \mathrm{H})$ ratio had no significant effect on the thermal comfort level at the pedestrian level (Muniz-Gäal, L. P., Pezzuto, C. C., de Carvalho, M. F. H., \& Mota, L. T. M. 2020). The sky view factor has increasingly got research attention in this particular research domain and is revealed as an essential parameter assessing urban microclimate. The sky-view factor is defined as the fraction of sky visible from a certain point in the street canyon, while the aspect ratio (AR) is the height of the adjacent buildings divided by the street width, which is also called H/W ratio. The relationship of these two is the lower sky view factor means higher aspect ratio and vice-versa and further recommended for planners and landscape architects, tall trees of low canopy density with high trunk in deeper canyons and vice-versa for shallow canyons and open-areas (Morakinyo et al 2017). According to Qaid, A., Lamit, H. B., Ossen, D. R., \& Rasidi, M. H. (2018), in urban street planning, SVF and the position of the visible sky regarding sun path and the cardinal directions should be considered for better understand the resultant micrometeorological and human thermal comfort conditions. Figure: 2 shows the variation of the physiological equivalent temperature (PET) affected by the position of the visible sky in the case of the NE-SW street direction. In urban heat island mitigation, geometry plays a vital role, and controlled sky view factor and inclusion of greenery affect microclimatic improvement. Urban design evaluation and decision must be corporate with SVF, because of its potential key role as a geometry parameter of urban design (Bourbia, F., \& Boucheriba, F. 2010). Previous research analysis demonstrated that orientation and aspect ratio strongly affect the magnitude and duration of the thermal peaks at the pedestrian level (Lobaccaro et al 2019). In terms of providing enhanced outdoor microclimate, East-West and Northwest-Southeast oriented roads had high PET values, and roads with North-South and Northeast-Southwest orientation have lower PET values (Zaki et al 2020). Moreover, the maximum comfort values for pedestrians were observed in north-south reoriented streets with high building height close to $100 \mathrm{~m}$. Further, buildings make additional shadow to nearby parks and enhance the comfort conditions within the park. (Ndetto, E. L., \& Matzarakis, A. (2013). 

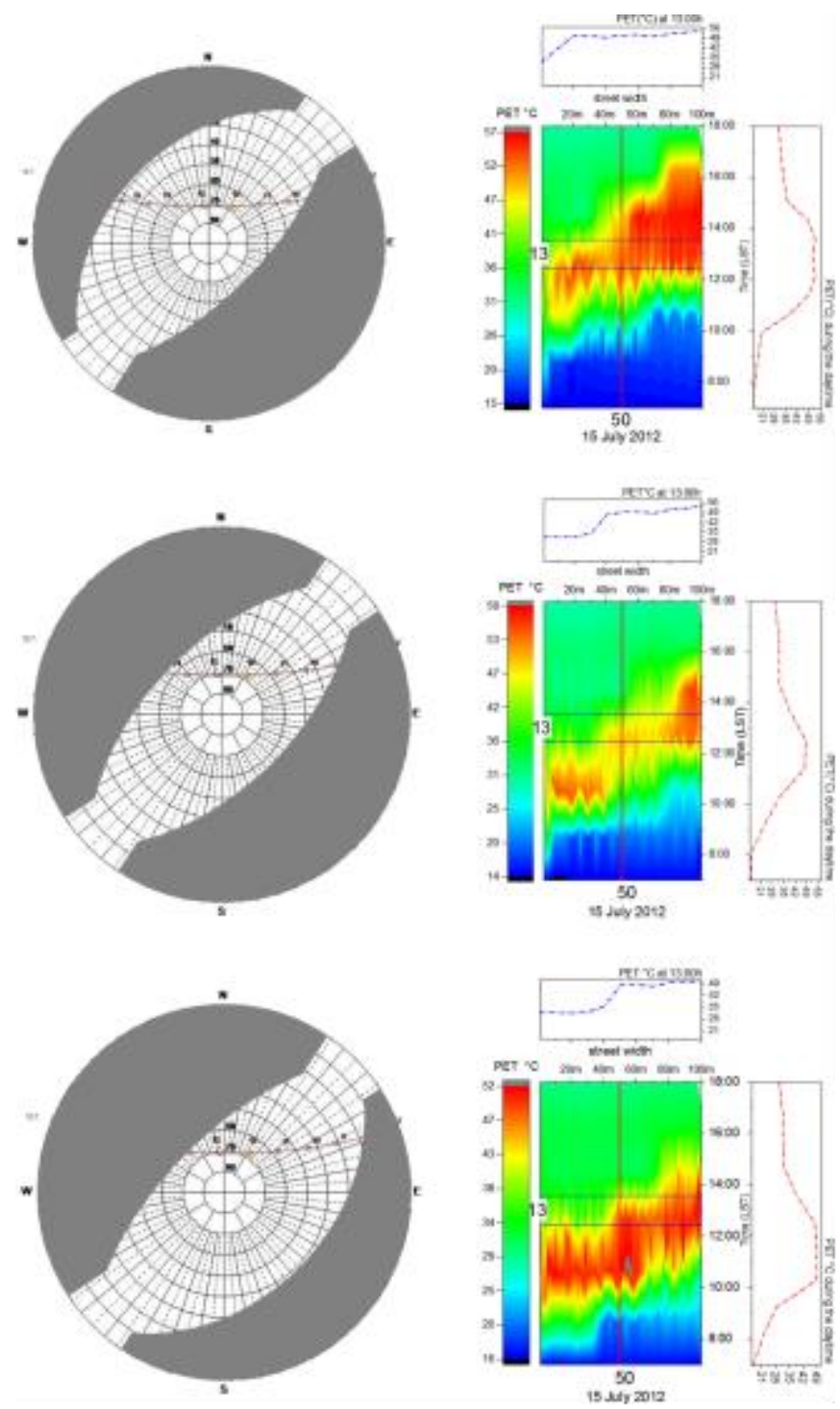

Figure 2: Variation of the physiological equivalent temperature (PET) affected by the position of the visible sky in the case of the NE-SW street direction (Qaid et al 2018). 


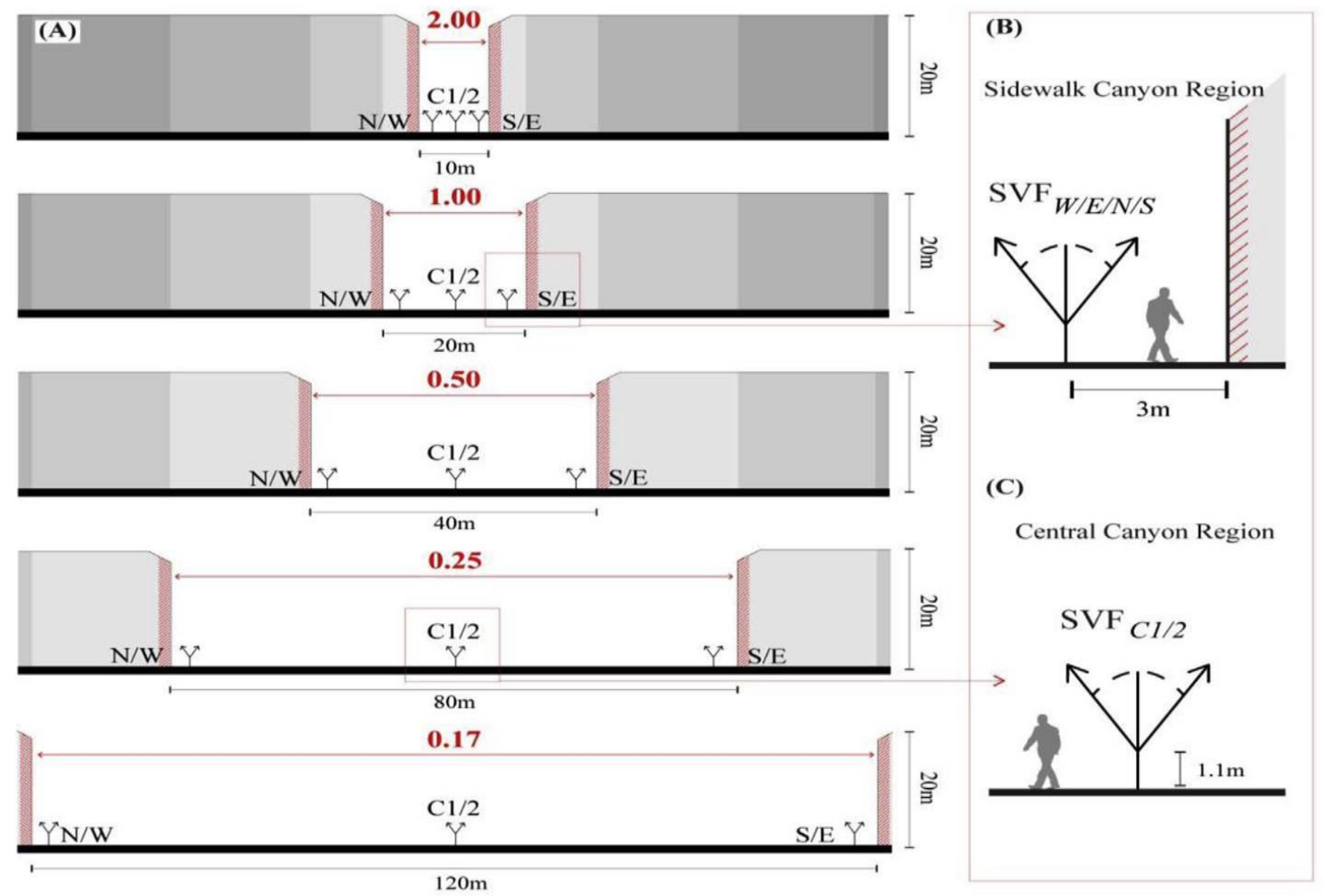

Figure 2: Layout of the determined Sky-View-Factors (SVF) within the four stipulated Aspect Ratios (AR) (Nouri, A. S., Costa, J. P., \& Matzarakis, A. 2017)

The outdoor thermal comfort in urban environments is closely driven by solar access, determined by the urban geometry, configurations, and density factors. For example, the geometry of a compacted urban canyon gives considerable shading by the surrounding buildings to maintain more comfortable conditions (Deng, J. Y., \& Wong, N. H. 2020). This review reveals that the impact of morphology factors of streets has received adequate research attention to investigate geometry parameters such as Sky- view factor, aspect ratios $(\mathrm{H} / \mathrm{W})$, and street axis orientation developing different scenarios with the inclusion of greenery. However, future research should be focused on other open space morphologies in an urban environment, namely squares and plazas, civic spaces, and parks instead of street canyon microclimate assessments.

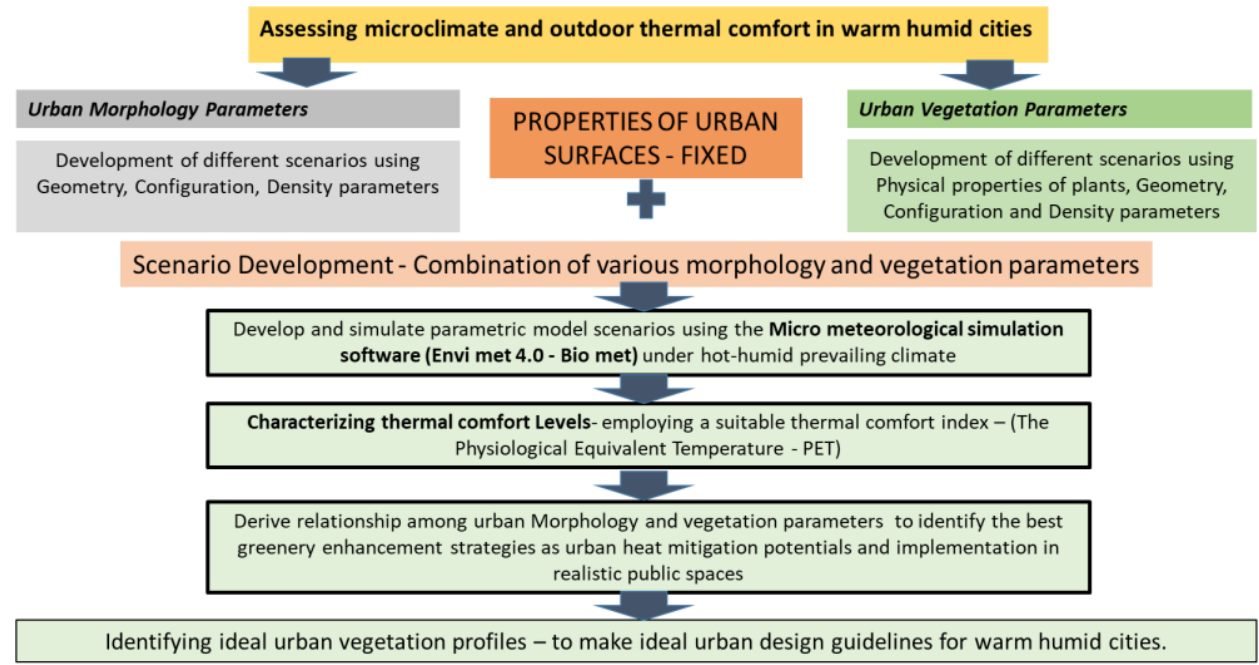

Figure 3: A theoretical framework for assessing the impact of urban design on outdoor thermal comfort in warm humid climates.

As the methodologies adopted to previous researches to assess the microclimate and thermal comfort level in urban spaces, micrometeorological simulation modeling employing thermal comfort indices 
in different proposed urban design scenarios have been increasingly identified. However, among the employed combinations, ENVI-met micro-meteorological simulation model employing Physiological Equivalent Temperature (PET) was found to be the most prominent research method in assessing microclimate and comfort in urban environments. As a result of this study, the following theoretical framework is proposed as shown in figure 4. Firstly, Scenario development is an important task combining morphology and vegetation parameters focusing on being investigated. The properties of urban spaces, such as albedos of façade and paving materials, should be fixed in the simulation process. Secondly, parametric model scenarios using the Micro meteorological simulation software (Envi met 4.0 - Bio met) and simulation under hot-humid prevailing climate characterize the thermal comfort Levels employing a suitable thermal comfort index (Physiological Equivalent Temperature PET) is proposed. Results help identify the best greenery enhancement strategies related to particular morphologies as urban heat mitigation potentials in realistic public spaces and recommend ideal urban vegetation profiles to make ideal urban design guidelines for warm, humid cities.

\section{Conclusion}

According to the results of recent Studies, the identified parameters of urban morphology and vegetation are categorized as parameters of geometry, density, configuration, and the physical properties of plants. Scenario developments for micrometeorological simulations could be processed considering the aforementioned categories to improve the microclimatic conditions. However, in literature, the Configuration of urban vegetation that affects the thermal comfort of urban spaces has not received adequate attention while the urban morphology has received considerable attention in previous research. Therefore, future research on the effects of planting patterns, arrangement of various species, and planting directions with prevailing wind conditions are to be considered. By the end of this review, a theoretical framework is suggested as an approach to assess the impact of urban vegetation and morphology parameters on outdoor thermal comfort in warm humid climates. The framework guides further research adopting more specific and comprehensive approaches with reference to specific urban morphologies to improve the local microclimate of cities, where the space for planting is critical. The findings of this review could be the basis for future research developing significant methodological approaches revealing diverse characteristics and properties of plants, different landscape patterns, and the effects of the various arrangements of elements in terms of microclimate improvements responding to particular urban morphologies. Accordingly, future studies would be more effective, finding vegetation configurations improving outdoor comfort, and maximizing the cooling effects of public spaces. Finally, landscape architects, policymakers, urban planners, and urban designers, can make climatic responsive design and planning decisions, to improve microclimate conditions and human outdoor comfort, and reduce the negative impact of urban heat Islands with their design interventions.

\section{Acknowledgement.}

This work is supported by the Accelerating Higher Education Expansion and Development (AHEAD) - DOR Grant affiliation with Ministry of Higher Education \& University Grants Commission and funded by the World Bank. 


\section{Reference}

Akbari, H., Bretz, S., Kurn, D. M., \& Hanford, J. (1997). Peak power and cooling energy savings of high-albedo roofs. Energy and Buildings, 25(2), 117-126.

Atwa, S., Ibrahim, M. G., \& Murata, R. (2020). Evaluation of plantation design methodology to improve the human thermal comfort in hot-arid climatic responsive open spaces. Sustainable Cities and Society, 59, 102198.

Barakat, A., Ayad, H., \& El-Sayed, Z. (2017). Urban design in favor of human thermal comfort for hot arid climate using advanced simulation methods. Alexandria Engineering Journal, 56(4), $533-$ 543.

Bourbia, F., \& Boucheriba, F. (2010). Impact of street design on urban microclimate for semi-arid climate (Constantine). Renewable Energy, 35(2), 343-347.

Bowler, D. E., Buyung-Ali, L., Knight, T. M., \& Pullin, A. S. (2010). Urban greening to cool towns and cities: A systematic review of the empirical evidence. Landscape and urban planning, 97(3), 147155.

Brysse, K., Oreskes, N., O’Reilly, J., \& Oppenheimer, M. (2013). Climate change prediction: Erring on the side of least drama?. Global environmental change, 23(1), 327-337.

De Abreu-Harbich, L. V., Labaki, L. C., \& Matzarakis, A. (2015). Effect of tree planting design and tree species on human thermal comfort in the tropics. Landscape and Urban Planning, 138, 99-109.

Declet-Barreto, J., Brazel, A. J., Martin, C. A., Chow, W. T., \& Harlan, S. L. (2013). Creating the park cool island in an inner-city neighborhood: heat mitigation strategy for Phoenix, AZ. Urban Ecosystems, 16(3), 617-635.

Deng, J. Y., \& Wong, N. H. (2020). Impact of urban canyon geometries on outdoor thermal comfort in central business districts. Sustainable Cities and Society, 53, 101966.

Dimoudi, A., \& Nikolopoulou, M. (2003). Vegetation in the urban environment: microclimatic analysis and benefits. Energy and buildings, 35(1), 69-76.

El-Bardisy, W. M., Fahmy, M., \& El-Gohary, G. F. (2016). Climatic sensitive landscape design: Towards a better microclimate through plantation in public schools, Cairo, Egypt. Procedia-Social and Behavioral Sciences, 216, 206-216.

Gromke, C., Blocken, B., Janssen, W., Merema, B., van Hooff, T., \& Timmermans, H. (2015). CFD analysis of transpirational cooling by vegetation: Case study for specific meteorological conditions during a heat wave in Arnhem, Netherlands. Building and environment, 83, 11-26.

Herath, H. M. P. I. K., Halwatura, R. U., \& Jayasinghe, G. Y. (2018). Evaluation of green infrastructure effects on tropical Sri Lankan urban context as an urban heat island adaptation strategy. Urban Forestry \& Urban Greening, 29, 212-222.

Huang, H. Y., Margulis, S. A., Chu, C. R., \& Tsai, H. C. (2011). Investigation of the impacts of vegetation distribution and evaporative cooling on synthetic urban daytime climate using a coupled LES - LSM model. Hydrological processes, 25(10), 1574-1586.

Jamei, E., Rajagopalan, P., Seyedmahmoudian, M., \& Jamei, Y. (2016). Review on the impact of urban geometry and pedestrian level greening on outdoor thermal comfort. Renewable and Sustainable Energy Reviews, 54, 1002-1017.

Koc, C. B., Osmond, P., \& Peters, A. (2018). Evaluating the cooling effects of green infrastructure: A systematic review of methods, indicators and data sources. Solar Energy, 166, 486-508.

Lee, H., \& Mayer, H. (2018). Maximum extent of human heat stress reduction on building areas due to urban greening. Urban Forestry \& Urban Greening, 32, 154-167.

Lee, H., Mayer, H., \& Chen, L. (2016). Contribution of trees and grasslands to the mitigation of human heat stress in a residential district of Freiburg, Southwest Germany. Landscape and Urban Planning, 148, 37-50. 
Lhotka, O., \& Kyselý, J. (2015). Characterizing joint effects of spatial extent, temperature magnitude and duration of heat waves and cold spells over Central Europe. International Journal of Climatology, $35(7), 1232-1244$.

Lobaccaro, G., Acero, J. A., Sanchez Martinez, G., Padro, A., Laburu, T., \& Fernandez, G. (2019). Effects of orientations, aspect ratios, pavement materials and vegetation elements on thermal stress inside typical urban canyons. International journal of environmental research and public health, 16(19), 3574.

Morakinyo, T. E., \& Lam, Y. F. (2016). Simulation study on the impact of tree-configuration, planting pattern and wind condition on street-canyon's micro-climate and thermal comfort. Building and Environment, 103, 262-275.

Morakinyo, T. E., Kong, L., Lau, K. K. L., Yuan, C., \& Ng, E. (2017). A study on the impact of shadow-cast and tree species on in-canyon and neighborhood's thermal comfort. Building and Environment, 115, 1-17.

Morakinyo, T. E., Lau, K. K. L., Ren, C., \& Ng, E. (2018). Performance of Hong Kong's common trees species for outdoor temperature regulation, thermal comfort and energy saving. Building and Environment, 137, 157-170.

Morakinyo, T. E., Ouyang, W., Lau, K. K. L., Ren, C., \& Ng, E. (2020). Right tree, right place (urban canyon): Tree species selection approach for optimum urban heat mitigation-development and evaluation. Science of The Total Environment, 719, 137461.

Muniz-Gäal, L. P., Pezzuto, C. C., de Carvalho, M. F. H., \& Mota, L. T. M. (2020). Urban geometry and the microclimate of street canyons in tropical climate. Building and Environment, 169, 106547.

Nasrollahi, N., Hatami, M., Khastar, S. R., \& Taleghani, M. (2017). Numerical evaluation of thermal comfort in traditional courtyards to develop new microclimate design in a hot and dry climate. Sustainable Cities and Society, 35, 449-467.

Ndetto, E. L., \& Matzarakis, A. (2013). Effects of urban configuration on human thermal conditions in a typical tropical African coastal city. Advances in Meteorology, 2013.

Ndetto, E. L., \& Matzarakis, A. (2015). Urban atmospheric environment and human biometeorological studies in Dar es Salaam, Tanzania. Air Quality, Atmosphere \& Health, 8(2), 175191.

Ng, E., Chen, L., Wang, Y., \& Yuan, C. (2012). A study on the cooling effects of greening in a highdensity city: An experience from Hong Kong. Building and environment, 47, 256-271.

Norton, B. A., Coutts, A. M., Livesley, S. J., Harris, R. J., Hunter, A. M., \& Williams, N. S. (2015). Planning for cooler cities: A framework to prioritise green infrastructure to mitigate high temperatures in urban landscapes. Landscape and urban planning, 134, 127-138.

Nouri, A. S., Costa, J. P., \& Matzarakis, A. (2017). Examining default urban-aspect-ratios and skyview-factors to identify priorities for thermal-sensitive public space design in hot-summer Mediterranean climates: The Lisbon case. Building and Environment, 126, 442-456.

Perini, K., \& Magliocco, A. (2014). Effects of vegetation, urban density, building height, and atmospheric conditions on local temperatures and thermal comfort. Urban Forestry \& Urban Greening, 13(3), 495-506.

Qaid, A., Lamit, H. B., Ossen, D. R., \& Rasidi, M. H. (2018). Effect of the position of the visible sky in determining the sky view factor on micrometeorological and human thermal comfort conditions in urban street canyons. Theoretical and applied climatology, 131(3), 1083-1100.

Robitu, M., Musy, M., Inard, C., \& Groleau, D. (2006). Modeling the influence of vegetation and water pond on urban microclimate. Solar energy, 80(4), 435-447.

Rodríguez-Algeciras, J., Tablada, A., \& Matzarakis, A. (2018). Effect of asymmetrical street canyons on pedestrian thermal comfort in warm-humid climate of Cuba. Theoretical and Applied Climatology, 133(3), 663-679. 
Roshan, G., Moghbel, M., \& Attia, S. (2020). Evaluating the wind cooling potential on outdoor thermal comfort in selected Iranian climate types. Journal of Thermal Biology, 92, 102660.

Salata, F., Golasi, I., de Lieto Vollaro, R., \& de Lieto Vollaro, A. (2016). Urban microclimate and outdoor thermal comfort. A proper procedure to fit ENVI-met simulation outputs to experimental data. Sustainable Cities and Society, 26, 318-343.

Shafaghat, A., Keyvanfar, A., Manteghi, G., \& Lamit, H. B. (2016). Environmental-conscious factors affecting street microclimate and individuals' respiratory health in tropical coastal cities. Sustainable Cities and Society, 21, 35-50.

Shahidan, M. F., Jones, P. J., Gwilliam, J., \& Salleh, E. (2012). An evaluation of outdoor and building environment cooling achieved through combination modification of trees with ground materials. Building and Environment, 58, 245-257.

Shashua-Bar, L., \& Hoffman, M. E. (2000). Vegetation as a climatic component in the design of an urban street: An empirical model for predicting the cooling effect of urban green areas with trees. Energy and buildings, 31(3), 221-235.

Shashua-Bar, L., Pearlmutter, D., \& Erell, E. (2011). The influence of trees and grass on outdoor thermal comfort in a hot-arid environment. International journal of climatology, 31(10), 1498-1506.

Shishegar, N. (2013). Street design and urban microclimate: analyzing the effects of street geometryand orientation on airflow and solar access in urban canyons. Journal of clean energy technologies, 1(1).

Sodoudi, S., Zhang, H., Chi, X., Müller, F., \& Li, H. (2018). The influence of spatial configuration of green areas on microclimate and thermal comfort. Urban Forestry \& Urban Greening, 34, 85-96.

Srivanit, M., \& Hokao, K. (2013). Evaluating the cooling effects of greening for improving the outdoor thermal environment at an institutional campus in the summer. Building and environment, 66, 158-172.

Su, W., Zhang, Y., Yang, Y., \& Ye, G. (2014). Examining the impact of greenspace patterns on land surface temperature by coupling LiDAR data with a CFD model. Sustainability, 6(10), 6799-6814.

Sun, S., Xu, X., Lao, Z., Liu, W., Li, Z., García, E. H., ... \& Zhu, J. (2017). Evaluating the impact of urban green space and landscape design parameters on thermal comfort in hot summer by numerical simulation. Building and Environment, 123, 277-288.

Taleghani, M., Kleerekoper, L., Tenpierik, M., \& Van Den Dobbelsteen, A. (2015). Outdoor thermal comfort within five different urban forms in the Netherlands. Building and environment, 83, 65-78.

Taleghani, M., Sailor, D. J., Tenpierik, M., \& van den Dobbelsteen, A. (2014). Thermal assessment of heat mitigation strategies: The case of Portland State University, Oregon, USA. Building and Environment, 73, 138-150.

Teshnehdel, S., Akbari, H., Di Giuseppe, E., \& Brown, R. D. (2020). Effect of tree cover and tree species on microclimate and pedestrian comfort in a residential district in Iran. Building and Environment, 178, 106899.

Tong, S., Wong, N. H., Tan, C. L., Jusuf, S. K., Ignatius, M., \& Tan, E. (2017). Impact of urban morphology on microclimate and thermal comfort in northern China. Solar Energy, 155, 212-223.

Tukiran, J. M., Ariffin, J., \& Ghani, A. N. A. (2017). A study on the cooling effects of greening for improving the outdoor thermal environment in Penang, Malaysia. International Journal of GEOMATE, 12(34), 62-70.

Unal, M., Uslu, C., Cilek, A., \& Altunkasa, M. F. (2018). Microclimate analysis for street tree planting in hot and humid cities. Journal of Digital Landscape Architecture, 3, 34-42.

Unit, E. I. (2011). Asian green city index. München: Siemens AG.

Vidrih, B., \& Medved, S. (2013). Multiparametric model of urban park cooling island. Urban Forestry \& Urban Greening, 12(2), 220-229. 
Wei, R., Song, D., Wong, N. H., \& Martin, M. (2016). Impact of urban morphology parameters on microclimate. Procedia Engineering, 169, 142-149.

Wong, N. H., Jusuf, S. K., \& Tan, C. L. (2011). Integrated urban microclimate assessment method as a sustainable urban development and urban design tool. Landscape and urban planning, 100(4), 386389.

Yahia, M. W., \& Johansson, E. (2014). Landscape interventions in improving thermal comfort in the hot dry city of Damascus, Syria-The example of residential spaces with detached buildings. Landscape and Urban Planning, 125, 1-16.

Yahia, M. W., Johansson, E., Thorsson, S., Lindberg, F., \& Rasmussen, M. I. (2018). Effect of urban design on microclimate and thermal comfort outdoors in warm-humid Dar es Salaam, Tanzania. International journal of biometeorology, 62(3), 373-385.

Yang, W., Lin, Y., \& Li, C. Q. (2018). Effects of landscape design on urban microclimate and thermal comfort in tropical climate. Advances in Meteorology, 2018.

Yoshida S, Murakami S, Ooka R, Mochida A, Tominaga Y (2000) CFD Prediction of Thermal Comfort in Microscale Wind Climate. Computational Wind Engineering, pp 27-30

Zaki, S. A., Toh, H. J., Yakub, F., Mohd Saudi, A. S., Ardila-Rey, J. A., \& Muhammad-Sukki, F. (2020). Effects of roadside trees and road orientation on thermal environment in a tropical city. Sustainability, 12(3), 1053.

Zhang, A., Bokel, R., van den Dobbelsteen, A., Sun, Y., Huang, Q., \& Zhang, Q. (2017). An integrated school and schoolyard design method for summer thermal comfort and energy efficiency in Northern China. Building and Environment, 124, 369-387.

Zhang, L., Zhan, Q., \& Lan, Y. (2018). Effects of the tree distribution and species on outdoor environment conditions in a hot summer and cold winter zone: A case study in Wuhan residential quarters. Building and Environment, 130, 27-39.

Zhang, Z., Lv, Y., \& Pan, H. (2013). Cooling and humidifying effect of plant communities in subtropical urban parks. Urban forestry \& urban greening, 12(3), 323-329.

Zhao, Q., Sailor, D. J., \& Wentz, E. A. (2018). Impact of tree locations and arrangements on outdoor microclimates and human thermal comfort in an urban residential environment. Urban Forestry \& Urban Greening, 32, 81-91.

Zhao, T. F., \& Fong, K. F. (2017). Characterization of different heat mitigation strategies in landscape to fight against heat island and improve thermal comfort in hot-humid climate (Part I): Measurement and modelling. Sustainable cities and society, 32, 523-531.

Zittis, G., Hadjinicolaou, P., Fnais, M., \& Lelieveld, J. (2016). Projected changes in heat wave characteristics in the eastern Mediterranean and the Middle East. Regional environmental change, 16(7), 1863-1876. 
Appendix 1; List of key Vegetation and morphology parameters analyzed by previous studies Assessing the thermal comfort effects of green spaces.

\begin{tabular}{|c|c|c|c|}
\hline No & $\begin{array}{l}\text { Author(s) and } \\
\text { year }\end{array}$ & Publishing journal & Key Parameters \\
\hline 1 & $\begin{array}{l}\text { Shashua-bar, } \\
\text { Pearlmutter, and } \\
\text { Erell (2011) }\end{array}$ & $\begin{array}{l}\text { International } \\
\text { Journal of } \\
\text { Climatology }\end{array}$ & $\begin{array}{l}\text { Landscape elements (trees, grass and } \\
\text { mesh) - Shading - Surfaces coverage } \\
\text { ratio }\end{array}$ \\
\hline 2 & $\begin{array}{l}\text { Huang, Margulis, } \\
\text { Chu, and Tsai } \\
\text { (2011) }\end{array}$ & Hydrological Processes & $\begin{array}{l}\text { Green space scale and distribution - } \\
\text { Urban surfaces }\end{array}$ \\
\hline 3 & $\begin{array}{l}\mathrm{Ng} \text {, Chen, Wang, } \\
\text { and Yuan (2012) }\end{array}$ & $\begin{array}{l}\text { Building and } \\
\text { Environment }\end{array}$ & $\begin{array}{l}\text { Building height- Building density - Type } \\
\text { of plant elements - Greenery ratio }\end{array}$ \\
\hline 4 & $\begin{array}{l}\text { Fairuz, Jones, } \\
\text { Gwilliam, and } \\
\text { Salleh (2012) }\end{array}$ & $\begin{array}{l}\text { Building and } \\
\text { Environment }\end{array}$ & $\begin{array}{l}\text { Ground materials albedo - Tree canopy } \\
\text { density - Tree quantity }\end{array}$ \\
\hline 5 & $\begin{array}{l}\text { Zhang et al. } \\
\text { (2013) }\end{array}$ & $\begin{array}{l}\text { Urban Forestry and } \\
\text { Urban Greening }\end{array}$ & $\begin{array}{l}\text { Canopy density - Canopy area - Tree } \\
\text { height - Type of plant communities }\end{array}$ \\
\hline 6 & $\begin{array}{l}\text { Srivanit and } \\
\text { Hokao }(2013)\end{array}$ & $\begin{array}{l}\text { Building and } \\
\text { Environment }\end{array}$ & $\begin{array}{l}\text { Canopy density - Grass coverage - Tree } \\
\text { and shrub coverage }\end{array}$ \\
\hline 7 & $\begin{array}{l}\text { Vidrih and } \\
\text { Medved (2013) }\end{array}$ & $\begin{array}{l}\text { Urban Forestry and } \\
\text { Urban Greening }\end{array}$ & $\begin{array}{l}\text { Tree age - Tree height - Crown height - } \\
\text { Crown diameter - Stem diameter - Leaf } \\
\text { area index }\end{array}$ \\
\hline 8 & Su et al. (2014) & Sustainability & $\begin{array}{l}\text { Vegetation type (tree or grass), } \\
\text { Vegetation height -Vegetation area, } \\
\text { Obstruction situation }\end{array}$ \\
\hline 9 & $\begin{array}{l}\text { Perini and } \\
\text { Magliocco (2014) }\end{array}$ & $\begin{array}{l}\text { Urban Forestry and } \\
\text { Urban Greening }\end{array}$ & $\begin{array}{l}\text { Building density - Building height - } \\
\text { Amount of green area Green areas type } \\
\text { (green roof and vegetation on the ground) }\end{array}$ \\
\hline 10 & $\begin{array}{l}\text { Taleghani et al. } \\
\text { (2014) }\end{array}$ & $\begin{array}{l}\text { Building and } \\
\text { Environment }\end{array}$ & Vegetation, Surfaces albedo \\
\hline 11 & $\begin{array}{l}\text { Gromke et al. } \\
\text { (2015) }\end{array}$ & $\begin{array}{l}\text { Building and } \\
\text { Environment }\end{array}$ & $\begin{array}{l}\text { Tree row, Façade greening, Roof } \\
\text { greening }\end{array}$ \\
\hline 12 & $\begin{array}{l}\text { De Abreuharbich } \\
\text { et al. (2015) }\end{array}$ & $\begin{array}{l}\text { Landscape and Urban } \\
\text { Planning }\end{array}$ & $\begin{array}{l}\text { Trunk geometry, Crown geometry, Tree } \\
\text { height, Permeability, Leaves type, Leaves } \\
\text { shape, Individual or cluster planting }\end{array}$ \\
\hline 13 & $\begin{array}{l}\text { Morakinyo et al. } \\
\text { (2017) }\end{array}$ & Building and Environment & $\begin{array}{l}\text { Leaf area index, Tree height, Trunk } \\
\text { height, Crown height and width }\end{array}$ \\
\hline 14 & $\begin{array}{l}\text { Zhao and Fong } \\
\text { (2017) }\end{array}$ & $\begin{array}{l}\text { Sustainable Cities and } \\
\text { Society }\end{array}$ & Leaf area index, Trees canopy density \\
\hline 15 & $\begin{array}{l}\text { Morakinyo, T. E., } \\
\text { \& Lam, Y. F. } \\
\text { (2016) }\end{array}$ & $\begin{array}{l}\text { Building and } \\
\text { Environment }\end{array}$ & $\begin{array}{l}\text { Varying aspect ratio, distribution and } \\
\text { trunk height ARB - } \\
\text { building height to road width ratio, ART- } \\
\text { tree height to crown diameter ratio.), leaf } \\
\text { area index (LAI), leaf area density (LAD }\end{array}$ \\
\hline 16 & $\begin{array}{l}\text { El-Bardisy et al. } \\
\text { (2016) }\end{array}$ & $\begin{array}{l}\text { Procedia - Social and } \\
\text { Behavioral Sciences }\end{array}$ & $\begin{array}{l}\text { Leaf area index and density - Landscape } \\
\text { elements - Trees arrangement and type - } \\
\text { Spatial location }\end{array}$ \\
\hline 17 & Lee et al. (2016) & $\begin{array}{l}\text { Landscape and Urban } \\
\text { Planning }\end{array}$ & Trees - Grasslands \\
\hline 18 & $\begin{array}{l}\text { Zhang et al. } \\
\text { (2018) }\end{array}$ & $\begin{array}{l}\text { Building and } \\
\text { Environment }\end{array}$ & $\begin{array}{l}\text { Tree height - Crown diameter - Leaf area } \\
\text { index - Leaf type - The aspect ratio of }\end{array}$ \\
\hline
\end{tabular}




\begin{tabular}{|c|c|c|c|}
\hline & & & trees \\
\hline 19 & Sun et al. (2017) & $\begin{array}{l}\text { Building and } \\
\text { Environment }\end{array}$ & $\begin{array}{l}\text { Grass - Tree - Hardened ground - } \\
\text { Waterbody - Building }\end{array}$ \\
\hline 20 & $\begin{array}{l}\text { Herath et al. } \\
\text { (2018a) }\end{array}$ & $\begin{array}{l}\text { Urban Forestry and } \\
\text { Urban Greening }\end{array}$ & Trees - Green roofs - Green walls \\
\hline 21 & Zhao et al. (2018) & $\begin{array}{l}\text { Urban Forestry and } \\
\text { Urban Greening }\end{array}$ & Tree location - tree layouts \\
\hline 22 & $\begin{array}{l}\text { Lee and Mayer } \\
\text { (2018) }\end{array}$ & $\begin{array}{l}\text { Urban Forestry and } \\
\text { Urban Greening }\end{array}$ & Asphalt surface - Green space - Building \\
\hline 23 & Unal et al. (2018) & $\begin{array}{l}\text { Digital Landscape } \\
\text { Architecture } 2018\end{array}$ & Tree crown density - Planting density \\
\hline 24 & $\begin{array}{l}\text { Morakinyo et al. } \\
(2018)\end{array}$ & $\begin{array}{l}\text { Building and } \\
\text { Environment }\end{array}$ & $\begin{array}{l}\text { The height of the tree - Trunk height - } \\
\text { Crown height - Crown diameter width - } \\
\text { Leaf area index }\end{array}$ \\
\hline 25 & $\begin{array}{l}\text { Sodoudi et al. } \\
\text { (2018) }\end{array}$ & $\begin{array}{l}\text { Urban Forestry and } \\
\text { Urban Greening }\end{array}$ & $\begin{array}{l}\text { Green areas direction - - The spatial } \\
\text { configuration of green areas }\end{array}$ \\
\hline 26 & $\begin{array}{l}\text { Hami et al. } \\
(2019) \text {. }\end{array}$ & $\begin{array}{l}\text { Sustainable Cities and } \\
\text { Society }\end{array}$ & $\begin{array}{l}\text { physical properties of plants, location and } \\
\text { vegetation cover, planting densities and } \\
\text { crown density, plant element, leaf type, } \\
\text { planting patterns and arrangement, and } \\
\text { Albedo }\end{array}$ \\
\hline 27 & $\begin{array}{l}\text { Nouri et al. } \\
(2018) \text {. }\end{array}$ & Atmosphere 2018 & $\begin{array}{l}\text { Urban vegetation, shelter canopies, } \\
\text { Surface materials, water/misting systems. }\end{array}$ \\
\hline 28 & Tong et al (2017) & Solar Energy & $\begin{array}{l}\text { building, pavement, greenery and water } \\
\text { area Leaf area, urban morphology } \\
\text { parameters, such as SVF, green plot ratio, } \\
\text { pavement percentage and building height } \\
\text { has been suggested }\end{array}$ \\
\hline 29 & $\begin{array}{l}\text { Yahia et al. } \\
(2018)\end{array}$ & $\begin{array}{l}\text { International Journal of } \\
\text { Biometeorology }\end{array}$ & $\begin{array}{l}\text { Building heights and orientations, spaces } \\
\text { between buildings, plot coverage alter } \\
\text { solar access, wind speed and direction at } \\
\text { street level. }\end{array}$ \\
\hline 30 & $\begin{array}{l}\text { Shishegar, } \\
\text { Nastaran (2013). }\end{array}$ & $\begin{array}{l}\text { Journal of clean energy } \\
\text { technologies }\end{array}$ & $\begin{array}{l}\text { streets geometry (H/W ratio) and } \\
\text { orientation on } \\
\text { airflow and solar access in an urban } \\
\text { canyon }\end{array}$ \\
\hline 31 & $\begin{array}{l}\text { Shafaghat et al. } \\
\text { (2016). }\end{array}$ & $\begin{array}{l}\text { Sustainable Cities and } \\
\text { Society }\end{array}$ & $\begin{array}{l}\text { Sky view factor }(\mathrm{SVF}), \text { Ratio }(\mathrm{H} / \mathrm{W}) \text {, } \\
\text { Street orientation, Asymmetrical shapes, } \\
\text { Urban Density and compactness }\end{array}$ \\
\hline 32 & $\begin{array}{l}\text { Yang, W., Lin, } \\
\text { Y., \& Li, C. Q. } \\
(2018) .\end{array}$ & $\begin{array}{l}\text { investigate the effects of } \\
\text { landscape design elements }\end{array}$ & $\begin{array}{l}\text { Pavement materials, greenery, and water } \\
\text { bodies }\end{array}$ \\
\hline 33 & $\begin{array}{l}\text { Rodríguez- } \\
\text { Algeciras et al. } \\
\text { (2018). }\end{array}$ & $\begin{array}{l}\text { Theoretical and Applied } \\
\text { Climatology }\end{array}$ & $\begin{array}{l}\text { Height-to-width ratio, street axis } \\
\text { orientations (N-S, NE-SW, E-W, SE- } \\
\text { NW), Asymmetrical street aspect ratios }\end{array}$ \\
\hline 34 & $\begin{array}{l}\text { Roshan, G., } \\
\text { Moghbel, M., \& } \\
\text { Attia, S. (2020). }\end{array}$ & Journal of thermal biology & $\begin{array}{l}\text { Urban Morphology, Sky veiw factor, } \\
\text { Shade coverage, Vegetation and water, } \\
\text { Street aspect ratio, Reflectivity }\end{array}$ \\
\hline 35 & Saeid et al. (2020) & Building and Environment & $\begin{array}{l}\text { Urban greening, Trees design, tree } \\
\text { species }\end{array}$ \\
\hline 36 & $\begin{array}{l}\text { Atwa, S., Ibrahim, } \\
\text { M. G., \& Murata, }\end{array}$ & Sustainable Cities and & Arrangement of trees; equal interval, \\
\hline
\end{tabular}


Proceedings of the $5^{\text {th }}$ International Conference on Climate Change, Vol. 5, Issue 1, 2021, pp. 1-17

\begin{tabular}{llll}
\hline & R. (2020) & Society & clustered, and random. \\
\hline 37 & Tukiran, J. M., & International Journal of & Tree coverage, density of canopy \\
& Ariffin, J., \& & Geomate & \\
Ghani, A. N. A. & \\
(2017) & & \\
\hline
\end{tabular}

